\title{
Extended Civil Commitment for Dangerous Psychiatric Patients
}

\author{
Linda E. Weinberger, PhD, Shoba Sreenivasan, PhD, and \\ Etan Markowitz, PhD
}

\begin{abstract}
Mental health clinicians are increasingly held civilly liable for the dangerous acts of their psychiatric patients. One area of liability is the negligent release of involuntarily committed patients who engage in dangerous acts after their hospital discharge. All states have provisions for extended involuntary commitment for mentally ill dangerous patients. We examined extended civil commitment petitions in Los Angeles County, California, and found that the great majority were rejected. While the standard for extended civil commitment in California includes verbal threats of substantial physical harm, deputy district attorneys tended to reject petitions initiated by clinicians when verbal threats were the sole criterion of dangerousness. This tendency by deputy district attorneys can be quite confusing for clinicians. Mental health professionals' liability has sensitized them to the legal implications of patients' verbal threats of harm; attorneys do not incur the same legal liability and are not so sensitized.
\end{abstract}

The emphasis on mental health professionals recognizing and diagnosing their psychiatric patients' risk of dangerousness has increased as cases are successfully litigated against clinicians and legislation is enacted that places the responsibility on mental health profes-

\footnotetext{
Dr. Weinberger is an Associate Professor of Clinical Psychiatry in the Department of Psychiatry and the Behavioral Sciences, University of Southern California (USC), Los Angeles, CA, and Chief Psychologist at the USC Institute of Psychiatry, Law, and Behavioral Science; Dr. Sreenivasan is a Clinical Associate Professor of Psychiatry in the Department of Psychiatry and the Behavioral Sciences, USC, Los Angeles, and Acting Assistant Chief of the Psychology Department at the West Los Angeles Veterans Affairs Medical Center; and Dr. Markowitz is a Clinical Assistant Professor of Psychiatry in the Department of Psychiatry and the Behavioral Sciences, USC, Los Angeles. Address correspondence to: Linda $\mathrm{E}$. Weinberger, PhD, USC Institute of Psychiatry, Law, and Behavioral Science, P.O. Box 86125, Los Angeles, CA 90086-0125.
}

sionals to determine and treat dangerousness. Involuntary hospitalization of mentally ill persons who are a danger to others represents one form of such responsibility. However, the obligation to protect the public also occurs at a time when resources for psychiatric care have become sparser and guidelines for involuntary psychiatric hospitalization are stricter. ${ }^{1-3}$ This challenge is heightened when clinicians do not seek extended involuntary commitments and are held civilly liable for the negligent release of hospitalized patients who commit dangerous acts after discharge. ${ }^{4-6}$

In the United States, the legal criteria for civil commitment include the presence of a mental illness that results in one or more of three conditions: danger to 
self, danger to others, or grave disability. Involuntary treatment for individuals who are a danger to others occurs in phases and is summarized in Table 1, using the 50 states' statutes as of 1994. Civil commitment begins with an initial period of hospitalization or an "emergency" detention and may be extended. The next phase in the civil commitment procedure applies to those who need additional treatment. If treatment is still warranted following the expiration of this phase, there is a third involuntary treatment period called an extended commitment term. Its duration varies among the states from 60 days to an indefinite period with periodic reviews. Following expiration of the extended civil commitment, the states allow for renewal of these commitments or additional, longer, commitment periods.

The stages of involuntary civil commitment are contingent upon continued mental illness and danger to others. For the initial period, danger to others is broadly defined in 28 states as "risk or threat of harm to others."* In 17 states, danger to others for the initial hospitalization is defined as recent behavior, attempts, or threats to physically harm others. ${ }^{\dagger}$ The remaining five states require, for the initial term of hospitalization, a "recent overt act of homicidal or other violent behavior" and/or violent behavior that places others in reasonable fear of serious harm. ${ }^{\ddagger}$ Of the 50 states, only 3 modify their danger to others standard when an

* AK, AZ, CA, CO, CT, DE, HI, ID, IL, IN, IA, KS, KY, LA, MD, MA, MN, MT, NM, ND, OH, OR, SC, SD, UT, VA, WA, WV.

${ }^{\dagger}$ FL, GA, MI, MS, MO, NE, NV, NH, NJ, NC, PA, RI, TN, TX, VT, WI, WY.

${ }^{\ddagger} \mathrm{AL}, \mathrm{AR}, \mathrm{ME}, \mathrm{OK}, \mathrm{NY}$ extended commitment is sought; 47 states maintain their standard for all succeeding commitment terms beyond the initial commitment. Alaska moves from a broad danger-to-others standard for the initial and additional commitment to a standard that requires recent behavior or attempts to inflict serious bodily harm on others. ${ }^{7}$ California and Washington change their nonspecific danger-to-others standard to one that requires recent behavior, attempts, or threats to physically harm others. ${ }^{8,9}$ The overt acts, attempts, or threats to inflict harm on others may precede the initial commitment or may occur during hospitalization.

In California, where our study was conducted, individuals whose mental illness results in a danger to others may be involuntarily hospitalized for an initial 72hour period. ${ }^{10}$ The nonspecific definition for the danger to others criterion does not change for the additional commitment term of 14 days, known as the "certification" period. ${ }^{11}$ However, for the 180-day extended commitment term known as "postcertification," the definition of danger to others changes and becomes specific. At this stage in the procedure, a person may be confined for further treatment if one of the following conditions exists:

(a) The person has attempted, inflicted, or made a serious threat of substantial physical harm upon the person of another after having been taken into custody, and while in custody, for evaluation and treatment, and who, as a result of mental disorder or mental defect, presents a demonstrated danger of inflicting substantial physical harm upon others.

(b) The person had attempted, or inflicted physical harm upon the person of another, that act 


\section{Extended Civil Commitment}

Table 1

Civil Commitment Periods in the United States

\begin{tabular}{|c|c|c|c|}
\hline \multirow[b]{2}{*}{$\begin{array}{l}\text { Length of } \\
\text { Stay }\end{array}$} & \multicolumn{3}{|c|}{ Commitment Period } \\
\hline & $\begin{array}{c}\text { Initial or emergency } \\
\text { period }\end{array}$ & Additional commitment & Extended commitment \\
\hline $24-72$ hours & $\begin{array}{l}\text { AK, AZ, CA, CO, } \\
\text { DE, FL, HI, ID, IN, } \\
\text { IA, KS, KY, ME, MI, } \\
\text { MD, MN, MT, NV, } \\
\text { NY, OH, OK, TX, } \\
\text { UT, VT, VA, WA, } \\
\text { WV, WI, WY }\end{array}$ & & \\
\hline $4-15$ days & $\begin{array}{l}\text { AL, AR, CT, GA, IL, } \\
\text { LA, MA, MS, MO, } \\
\text { NE, NH, NJ, NM, } \\
\text { NC, ND, OR, PA, } \\
\text { RI, SC, SD, TN }\end{array}$ & & \\
\hline 3-30 days & & $\begin{array}{l}\text { AK, CA, CT, DE, IA, } \\
\text { MO, NM, NY, ND, OH, } \\
\text { OK, PA, SC, TN, WA }\end{array}$ & \\
\hline $45-180$ days & & $\begin{array}{l}\text { AL, AZ, AR, CO, FL, } \\
\text { GA, HI, IL, IN, KS, KY, } \\
\text { ME, MA, MI, MN, MS, } \\
\text { MT, NE, NV, NJ, NC, } \\
\text { OR, RI, SD, TX, UT, } \\
\text { VT, VA, WV, }{ }^{a} \text { WI }\end{array}$ & \\
\hline 60 days & & & IA \\
\hline 90 days & & & $\begin{array}{l}\text { AK, HI, IN, KS, MI, MO, } \\
\text { ND, OH, PA, TN, WA }\end{array}$ \\
\hline 180 days & & & $\begin{array}{l}\text { AZ, AR, CA, CO, DE, FL, } \\
\text { IL, MT, NV, NJ, NM, NY, } \\
\text { NC, OR, RI, SC, SD, VA }\end{array}$ \\
\hline One year & & MD & $\begin{array}{l}\text { AL, GA, KY, ME, MD, MA, } \\
M N, T X, W 1\end{array}$ \\
\hline Indefinite & & $\mathrm{ID},{ }^{b} \mathrm{LA}, \mathrm{NH},{ }^{c} \mathrm{WY}$ & CT, MS, NE, OK, UT, VT \\
\hline
\end{tabular}

Temporary observation period not to exceed 6 months or indeterminate period not to exceed 2 years.

DNot to exceed 3 years.

Not to exceed 5 years. 
having resulted in his or her being taken into custody and who presents, as a result of mental disorder or mental defect, a demonstrated danger of inflicting substantial physical harm upon others.

(c) The person had made a serious threat of substantial physical harm upon the person of another within seven days of being taken into custody, that threat having at least in part resulted in his or her being taken into custody, and the person presents, as a result of mental disorder or mental defect, a demonstrated danger of inflicting substantial physical harm upon others. ${ }^{8}$

Petitions for postcertification are filed by the professional person in charge of the health facility or his or her designee (a psychiatrist or psychologist). ${ }^{12} \mathrm{~A}$ public officer, usually the district attorney's office, reviews the petition, including affidavits, and decides whether to proceed further and present the case in superior court for an order requiring the patient to undergo an additional 180-day period of treatment. If the deputy district attorney decides to file the petition, a judicial hearing is mandatory and patients are represented by counsel; patients may request a jury trial.

Our experience with involuntary hospitalization suggests that few individuals who are initially committed under the danger-to-others criterion remain hospitalized beyond the certification (additional) period and that very few postcertification (extended) commitment petitions are actually filed by clinicians. Some of our colleagues in county, state, and Veterans Affairs hospitals perceive that legal professionals view dangerousness in psychiatric patients to consist only of recent violent behavior, despite the standard including verbal threats as a criterion for extended commitment. We examined the application of this standard by clinicians and legal professionals focusing on which factors, if any, contributed to the differences between mental health and legal professionals in pursuing and granting postcertifications.

\section{Method}

Los Angeles County has a large number of mentally ill individuals treated psychiatrically within local, state, and Veterans Affairs hospitals. One superior court, in the Mental Health Department, hears all civil commitment cases within the county. This centralized process allows the same court personnel to work on all cases and have available in one location all psychiatric and legal material relevant to postcertification petitions.

This study was conducted under the auspices of the Los Angeles County District Attorney's Office at the Mental Health Department. We reviewed all postcertification petitions (the 180-day hold for patients who are dangerous to others) filed between January 1989 and June 1993. A total of 69 petitions was filed during this period. In two cases, the files could not be located. Of the remaining 67 petitions, one case was refiled within the study period; thus, the study population consisted of 66 patients. Sixty-five patients were either initially committed (72-hour hold) as a danger to others and/or certified (14-day hold) as a danger to others. One postcertification petition was filed on an individual who was committed as a "not guilty by reason of insanity" acquittee.

In California, judicial proceedings for 
postcertification are presented by the district attorney or county counsel. ${ }^{13}$ In Los Angeles County, postcertification petitions are submitted by the treatment facility's psychiatrist or psychologist to the district attorney's office. The deputy district attorney has the option to proceed with the petition or to decline to file it.

The files reviewed included all evidence used by the District Attorney's Office in postcertification hearings. These included the petition submitted by the psychiatric hospital, affidavits completed by two or more persons who had witnessed and detailed the patient's dangerous behavior, the deputy district attorney's summary of the case, and the independent mental health evaluator's report. The independent evaluator is a psychiatrist or psychologist appointed by the court to perform an impartial evaluation of whether the patient meets the postcertification criteria. Independent evaluators are not appointed in every case. The cases reviewed also included the results of the deputy district attorney's decision to file the petition and, for filed petitions, the court's or jury's decision concerning the outcome (i.e., whether the postcertification petition was granted or denied).

There were missing data in the files of many patients; their files could be considered incomplete. However, what was available for our review was usually all that had been considered by the deputy district attorney in deciding whether to proceed with the petition. It is not uncommon for decisions on whether to seek extended civil commitments to be based on limited data. ${ }^{14}$

\section{Results}

The 66 patients comprised three (sub) groups. For $40(61 \%)$ patients, postcertification petitions were filed by the hospital, but did not proceed further in court because their cases were rejected by the deputy district attorney prior to the court hearing (termed DA Rejected; of these 40, 7 petitions fell into this category because the hospital withdrew the petition). For seven $(11 \%)$ patients, postcertification petitions were filed by the hospital and accepted by the deputy district attorney, but were found not to meet the postcertification criteria by the court or jury (Court Rejected). For 19 (29\%) patients, postcertification petitions were filed by the hospital, accepted by the deputy district attorney, and found to meet the postcertification criteria by the court or jury (Court Accepted).

Given the small number of petitions filed and the small percentage accepted by the deputy district attorney and the court, we considered the possibility that clinicians had been dissuaded from filing postcertifications. Table 2 cross-tabulates

Table 2

Year of Filing and Petition Outcome

\begin{tabular}{lccc}
\hline \multirow{2}{*}{$\begin{array}{c}\text { Year Petition } \\
\text { Filed }\end{array}$} & \multicolumn{3}{c}{ Petition Outcome } \\
\cline { 2 - 4 } & $\begin{array}{c}\text { DA } \\
\text { rejected }\end{array}$ & $\begin{array}{c}\text { Court } \\
\text { rejected }\end{array}$ & $\begin{array}{c}\text { Court } \\
\text { accepted }\end{array}$ \\
\hline 1989 & 8 & 2 & 8 \\
1990 & 17 & 2 & 4 \\
1991 & 7 & 2 & 1 \\
1992 & 4 & 1 & 4 \\
January-June 1993 & 4 & 0 & 2 \\
\hline
\end{tabular}


Table 3

Patient Characteristics and Petition Outcome

\begin{tabular}{|c|c|c|c|}
\hline \multirow[b]{2}{*}{ Characteristics } & \multicolumn{3}{|c|}{ Petition Outcome } \\
\hline & $\begin{array}{c}\text { DA rejected } \\
N=40\end{array}$ & $\begin{array}{l}\text { Court rejected } \\
\qquad N=7\end{array}$ & $\begin{array}{l}\text { Court accepted } \\
\qquad N=19\end{array}$ \\
\hline \multicolumn{4}{|l|}{ Race } \\
\hline White & $16(40 \%)^{a}$ & $4(57 \%)$ & $6(32 \%)$ \\
\hline African American & $9(22 \%)$ & $2(29 \%)$ & $7(37 \%)$ \\
\hline Hispanic & $3(8 \%)$ & $1(14 \%)$ & $4(21 \%)$ \\
\hline Asian & $2(5 \%)$ & 0 & 0 \\
\hline Unknown & $10(25 \%)$ & 0 & $2(11 \%)$ \\
\hline \multicolumn{4}{|l|}{ Previous hospitalization } \\
\hline Yes & $26(65 \%)$ & $5(71 \%)$ & $15(79 \%)$ \\
\hline No & $3(8 \%)$ & $1(14 \%)$ & $3(16 \%)$ \\
\hline Unknown & $11(28 \%)$ & $1(14 \%)$ & $1(5 \%)$ \\
\hline \multicolumn{4}{|l|}{ Substance abuse history } \\
\hline Yes & $18(45 \%)$ & $3(43 \%)$ & $13(68 \%)$ \\
\hline No & $6(15 \%)$ & $3(43 \%)$ & $3(16 \%)$ \\
\hline Unknown & $16(40 \%)$ & $1(14 \%)$ & $3(16 \%)$ \\
\hline \multicolumn{4}{|l|}{ Arrest history } \\
\hline Threat crimes $^{b}$ & $2(5 \%)$ & 0 & $2(11 \%)$ \\
\hline Violent crimes & $12(30 \%)$ & $4(57 \%)$ & $7(37 \%)$ \\
\hline Nonviolent crimes & $7(18 \%)$ & $1(14 \%)$ & $3(16 \%)$ \\
\hline No arrest history & $5(12 \%)$ & 0 & $1(5 \%)$ \\
\hline Unknown & $14(35 \%)$ & $2(29 \%)$ & $6(32 \%)$ \\
\hline \multicolumn{4}{|l|}{ History of incarceration } \\
\hline Yes & $12(30 \%)$ & $5(71 \%)$ & $10(53 \%)$ \\
\hline No & $8(20 \%)$ & 0 & $2(11 \%)$ \\
\hline Unknown & $20(50 \%)$ & $2(29 \%)$ & $7(37 \%)$ \\
\hline \multicolumn{4}{|l|}{ Prior history of violence } \\
\hline Physically assaultive ${ }^{c}$ & $23(58 \%)$ & $4(57 \%)$ & $9(47 \%)$ \\
\hline Threats to harm others & $1(2 \%)$ & 0 & $4(21 \%)$ \\
\hline No history of violence & $16(40 \%)$ & $3(43 \%)$ & $6(32 \%)$ \\
\hline
\end{tabular}

aThe percentage of each Characteristic subgroup within its Petition Outcome group is in parentheses.

${ }^{b}$ Includes arrests for making threatening phone calls, harassing a neighbor, and threatening to harm elected officials.

includes history of arrests for violent crimes and history of assaultive behavior without arrest.

petition outcome against year of filing. To examine whether there was a change over the time span of our study toward filing petitions, we tested for a relationship between petition outcome and year by the Pearson Chi-Square Test. There is no statistically significant deviation from independence $\left(\chi^{2}=8.178, d f=8, p=\right.$ $.42)$.
Patient age ranged from 22 to 71 years in the DA Rejected group (median $=34$ ), 21 to 40 years in the Court Rejected group (median $=34.5$ ), and 23 to 51 years in the Court Accepted group (median $=32)$. Thirty-three $(82 \%)$ of the DA Rejected group were male, $4(57 \%)$ of the Court Rejected group were male, and 18 (95\%) in the Court Accepted group were 
Table 4

Commitment Site and Diagnostic Information and Petition Outcome

\begin{tabular}{lccc}
\hline \multicolumn{1}{c}{ Factors } & \multicolumn{3}{c}{ Petition Outcome } \\
\cline { 2 - 4 } \multicolumn{1}{c}{} & $\begin{array}{c}\text { DA rejected } \\
N=40\end{array}$ & $\begin{array}{c}\text { Court rejected } \\
N=7\end{array}$ & $\begin{array}{c}\text { Court accepted } \\
N=19\end{array}$ \\
\hline Psychiatric hospital & & & \\
State hospital & $7(18 \%)^{a}$ & $5(71 \%)$ & $3(16 \%)$ \\
County hospital & $11(28 \%)$ & $1(14 \%)$ & $10(53 \%)$ \\
Private hospital & $15(38 \%)$ & $1(14 \%)$ & $4(21 \%)$ \\
VA hospital & $7(18 \%)$ & 0 & 0 \\
Jail hospital & 0 & 0 & $2(10 \%)$ \\
Psychiatric diagnosis & & & $15(79 \%)$ \\
Schizophrenia/psychosis NOS ${ }^{b}$ & $26(65 \%)$ & $4(57 \%)$ & $2(10 \%)$ \\
Mood disorder & $8(20 \%)$ & $2(28 \%)$ & 0 \\
Delusional disorder & $2(5 \%)$ & $1(14 \%)$ & 0 \\
Pedophilia & $1(2 \%)$ & 0 & 0 \\
Organic psychosis & $1(2 \%)$ & 0 & $1(5 \%)$ \\
Pyromania & $1(2 \%)$ & 0 & 0 \\
Borderline personality & 0 & 0 & \\
Unknown & $1(2 \%)$ & 0 & \\
\hline
\end{tabular}

${ }^{a}$ The percentage of each Factor subgroup within its Petition Outcome group is in parentheses.

${ }^{b}$ NOS, not otherwise specified.

male. Other demographic and clinical data for the three groups are summarized in Table 3.

Table 4 cross-tabulates the type of psychiatric facility in which the patient was hospitalized against diagnostic information contained in the postcertification petitions. The most frequent psychiatric diagnosis in all groups was a psychotic disorder.

Independent evaluators were used for $31(47 \%)$ of the 66 cases filed. In those instances in which the independent evaluator agreed with the hospital, 3 cases were rejected by the deputy district attorney; 3 were accepted by the deputy district attorney and had a hearing, but were rejected by the court; and 10 were accepted by the deputy district attorney, had a hearing, and were accepted by the court. When the independent evaluator dis- agreed with the hospital, 14 cases were rejected by the deputy district attorney, and 1 was accepted by the deputy district attorney but was rejected after a hearing by the court. There were no cases in which the independent evaluator disagreed with the hospital and the court granted the postcertification petition.

For the seven cases that were accepted by the deputy district attorney but rejected by the court, the trier-of-fact was a judge in six $(86 \%)$ cases and a jury in one $(14 \%)$. When a postcertification petition was granted by the court, the trier-of-fact was a judge in $16(84 \%)$ cases, a jury in 1 $(5 \%)$ case, and unknown in $2(11 \%)$ cases.

For the criteria supporting the postcertification petition, the material was scored as verbal threats only, behavioral manifestations of aggression only, or both 
Weinberger, Sreenivasan, and Markowitz

Table 5

Supporting Criteria and Petition Outcome

\begin{tabular}{lccc}
\hline Criteria & \multicolumn{3}{c}{ Petition Outcome } \\
\cline { 2 - 4 } $\begin{array}{c}\text { Supporting } \\
\text { Postcertification }\end{array}$ & $\begin{array}{c}\text { DA } \\
\text { Petition }\end{array}$ & $\begin{array}{c}\text { Court } \\
\text { rejected }\end{array}$ & $\begin{array}{c}\text { Court } \\
\text { rejected } \\
\text { accepted }\end{array}$ \\
\hline $\begin{array}{c}\text { Verbal threat only } \\
\text { Behavioral }\end{array}$ & 18 & 2 & 1 \\
$\begin{array}{l}\text { manifestation of } \\
\text { aggression only }\end{array}$ & 3 & 2 & 6 \\
Both & 19 & 3 & 12 \\
\hline
\end{tabular}

(verbal threats and behavioral manifestations of aggression). The criteria used to support the postcertification petition either precipitated the current hospitalization or occurred during the hospitalization. Verbal threats consisted of threatening to kill or injure family members, staff, politicians, or others in the community. Behavioral manifestations of aggression included episodes of physical aggression toward family members, staff, or others; sending threatening messages by mail or telephone to others; engaging in stalking behavior; destroying hospital furniture; and brandishing weapons.

Table 5 cross-tabulates the postcertification criteria against petition outcome. The possibility of a relationship between criteria and petition outcome was tested by the Likelihood Ratio Test for Independence. ${ }^{15}$ The Likelihood Ratio Test is asymptotically equivalent to the traditional Pearson Chi-Square Test, but is preferable here because it permits a meaningful partition of the chi-square statistic into independent follow-up tests. There is a highly statistically significant relationship between criteria supporting petition and petition outcome $\left(\chi^{2}=14.19, d f=4\right.$,
Table 6

Supporting Criteria and DA's Action

\begin{tabular}{lcc}
\hline & \multicolumn{2}{c}{ DA's Action } \\
\cline { 2 - 3 } $\begin{array}{c}\text { Criteria Supporting } \\
\text { Postcertification Petition }\end{array}$ & $\begin{array}{c}\text { DA } \\
\text { rejected }\end{array}$ & $\begin{array}{c}\text { DA } \\
\text { accepted }\end{array}$ \\
\hline $\begin{array}{l}\text { Verbal threats only } \\
\text { Behavioral manifestation } \\
\quad \text { of aggression only }\end{array}$ & 3 & 3 \\
Both & 19 & 8 \\
\hline
\end{tabular}

$p=.0067)$. To identify the source of the relationship, Table 5 was partitioned into Tables 6 and 7. Table 6 examines the relationship between criteria supporting the petition and the deputy district attorney's action, for which there is a highly statistically significant relationship $\left(\chi^{2}=\right.$ $11.72, d f=2, p=.0028)$. The deputy district attorney tended to reject cases that were brought forward by the psychiatric hospitals based on verbal threats only. Table 7 examines the relationship between criteria supporting the petition and the court's action on those petitions that were accepted by the deputy district attorney. There was no statistically significant relationship $\left(\chi^{2}=2.46, d f=2, p=\right.$ .29). The court was not influenced by the nature of the criteria supporting the petition. Note that the overwhelming majority of petitions reviewed by the court con-

Table 7

Supporting Criteria and Court's Action

\begin{tabular}{lcc}
\hline \multirow{2}{*}{$\begin{array}{c}\text { Criteria Supporting } \\
\text { Postcertification Petition }\end{array}$} & \multicolumn{2}{c}{ Court's Action } \\
\cline { 2 - 3 } & $\begin{array}{c}\text { Court } \\
\text { rejected }\end{array}$ & $\begin{array}{c}\text { Court } \\
\text { accepted }\end{array}$ \\
\hline $\begin{array}{l}\text { Verbal threats only } \\
\text { Behavioral manifestation } \\
\quad \begin{array}{l}\text { of aggression only } \\
\text { Both }\end{array}\end{array}$ & 2 & 1 \\
\hline
\end{tabular}


Extended Civil Commitment

Table 8

History of Violence and Petition Outcome

\begin{tabular}{|c|c|c|c|}
\hline \multirow[b]{2}{*}{$\begin{array}{l}\text { History of } \\
\text { Violence }\end{array}$} & \multicolumn{3}{|c|}{ Petition Outcome } \\
\hline & $\begin{array}{c}D A \\
\text { rejected }\end{array}$ & $\begin{array}{c}\text { Court } \\
\text { rejected }\end{array}$ & $\begin{array}{c}\text { Court } \\
\text { accepted }\end{array}$ \\
\hline Yes & 24 & 4 & 13 \\
\hline No & 16 & 3 & 6 \\
\hline
\end{tabular}

tained behavioral manifestations of aggression.

A history of violence was also included by the hospital clinicians as a factor used to support the postcertification petition. Table 8 cross-tabulates history of violence against petition outcome. The possibility of a relationship between history of violence and petition outcome was tested by the Likelihood Ratio Test for Independence. There was no statistically significant relationship between history of violence and petition outcome $\left(\chi^{2}=\right.$ $0.48, d f=2, p=.79)$. There was no statistically significant relationship $\left(\chi^{2}=\right.$ $0.20, d f=1, p=.66$ ) between history of violence and the deputy district attorney's action. Also, there was no statistically significant relationship $\left(\chi^{2}=0.28, d f=\right.$ $1, p=.60$ ) between history of violence and the court's action.

\section{Discussion}

Our data suggest that clinicians considered a broader base of factors in making their determinations as to which patients required an extended period of commitment under the dangerousness criterion than did the deputy district attorneys. Clinicians tended to seek postcertification petitions on individuals with a previous history of psychiatric hospitalization, substance abuse, arrests for violent crimes, and physical assaults. In addition, clinicians were likely to file petitions on patients who suffered from a psychotic or mood disorder; who expressed verbal threats of serious bodily injury to others, family, or both; and who demonstrated a variety of behavioral manifestations including assaulting others prior to and during hospitalization, stalking, and sending threatening letters or making threatening telephone calls to others prior to or during hospitalization. The deputy district attorneys were not influenced by many of the factors identified by clinicians as relevant to dangerousness. For example, a patient's history of violence appears to have made no difference in whether the deputy district attorneys accepted or rejected the postcertification petition. We also found that deputy district attorneys tended to reject postcertification petitions that were brought forward by the psychiatric hospitals based only on verbal threats.

We believe the disparity in opinions between clinicians and district attorneys as to material relevant for extended commitments is due in part to the legal responsibility placed upon clinicians in identifying dangerousness. Clinicians have incurred increasing legal responsibility for the accurate recognition, assessment, and treatment of psychiatric patients who pose a risk of danger to the public. Consequently, they may have a tendency to approach the assessment of dangerousness broadly and in terms of risk factors. If a factor is identified in the professional literature and research as a significant risk variable associated with dangerous behavior, then an informed cli- 
nician who observes it in the patient is more likely to identify that individual as posing a threat of harm. For example, research indicates that individuals who suffer from a psychotic disorder and abuse alcohol or drugs are more likely to engage in acts of violence toward others than individuals without mental illness. ${ }^{16}$ Further, individuals who suffer from erotomanic delusions pose a high risk of stalking their targets. ${ }^{17,}{ }^{18}$ Clinicians also rely on certain demographic variables identified in the research as associated with dangerousness, such as younger males with a prior history of violent arrest, ${ }^{19}$ or on actuarial methods that combine demographic and clinical variables. ${ }^{20}$ Therefore, it is not surprising that the clinicians in our study used these and other clinical factors in forming their opinions about the patients' dangerousness.

Clinicians' increasing sensitivity to identifying dangerousness may be influenced by cases in which they have been held legally liable for the dangerous acts of their patients. Such liability can be incurred on the basis of narrow Tarasofflike situations in which a patient has made serious verbal threats of harm to an identifiable person(s) and the therapist incurs a duty to protect/warn the potential victim. ${ }^{21}$ In some states, the therapist's duty is satisfied by initiating civil commitment or voluntary hospitalization. ${ }^{22}$ Another instance in which clinicians have incurred liability is in the negligent release of psychiatric inpatients who later commit acts of violence. In this broader situation, clinicians have a duty to protect public safety. In these cases, the psychi- atric inpatients may not have made a specific threat toward identifiable persons, but still pose a threat to others if released. Two landmark decisions illustrate such situations.

In Petersen v. State of Washington, ${ }^{4}$ a patient, five days after release, having disposed of his psychotropic medications and being under the influence of drugs, injured an individual in the community when his vehicle struck hers. The Washington State Supreme Court opined that the state hospital psychiatrist "incurred a duty to take reasonable precautions to protect anyone who might foreseeably be endangered" by a patient's drug-related mental problems (p. 237). The Court also said that the psychiatrist was liable for failing to petition for an extended 90-day civil commitment or take other reasonable steps to protect people who might be at risk because of the patient's drugrelated mental condition. In Perriera $v$. State of Colorado, ${ }^{5}$ the court opined that a psychiatrist could be held responsible for a psychiatric patient's dangerous behavior which occurred four months after his release from an involuntary psychiatric hospitalization. The patient shot and killed a police officer who responded to a call of disturbance created by the patient at a convenience store. The Colorado Supreme Court held that the psychiatrist "had a legal duty to exercise due care to determine whether the patient had a propensity for violence and would thereby present an unreasonable risk of serious bodily harm to others if released from the involuntary commitment" (p. 1198). The court further stated that in discharging this duty, the psychiatrist may be required 
to take reasonable precautions to protect the public, including the "giving of due consideration to extending the term of the patient's commitment or placing appropriate conditions or restrictions on the patient's release" (p. 1198).

Successful judgments against clinicians for the violent acts committed by their patients even months after the patients' release from a psychiatric hospitalization contribute to reinforcing a "defensive" form of clinical practice. Indeed, some authors have suggested that defensive motives play an active role in clinicians committing patients under involuntary psychiatric holds. ${ }^{23,24}$ Given that many states have laws under which clinicians incur a duty to protect when their patient makes a threat of physical violence against others, ${ }^{22}$ it is not surprising that clinicians take verbal threats of bodily harm seriously. As noted earlier, many states' civil commitment standard for danger to others includes "threats to physically harm others." Studies have found that such threats, with or without action to execute them, comprise a significant portion of civil commitments initiated or continued under the "dangerousness" standard. ${ }^{25,26}$

Our data reveal that patients' verbal threats of harm were among the criteria supporting postcertification petitions filed by clinicians. Verbal threats of serious bodily injury to family, others, or both were present in 55 of the 66 petitions filed by clinicians. Verbal threats of bodily injury to others was the sole criterion in 21 of the 66 petitions filed by clinicians. Interestingly, while clinicians attached significance to such verbal threats, deputy district attorneys were not as likely to find verbal threats alone as convincingly supportive of a petition for postcertification. Thus, the majority of such cases were ultimately rejected by the deputy district attorneys.

This tendency by deputy district attorneys to reject postcertification petitions when verbal threats serve as the supporting data can be quite confusing for the practicing therapist. In California, verbal threats of harm to others are recognized by the law as one of the grounds for postcertification. ${ }^{8}$ Thus, it would not be unusual for the treating clinician to apply the postcertification standard literally and attach significance to a patient's verbal threats of harm to family members, others, or both. That deputy district attorneys do not attach significance in these situations may be explained in two ways. One is that legal professionals are trained to consider only those factors having a strong nexus to the legal issue; that is, does the patient present a demonstrated danger of inflicting substantial physical harm upon others? Legal professionals may not be inclined to believe that verbal threats of harm lead to violent behavior. Second, attorneys, unlike treating clinicians, do not have the legal responsibility and resultant liability for correctly identifying dangerous mentally ill individuals and protecting the public from them. Consequently, these legal professionals may either minimize the significance of verbal threats or be reluctant to accept them, and thus decide that the patient's verbal threats are not serious.

It is of interest that in a county as large as Los Angeles, so few postcertification 
petitions were filed during the 3.5-year period of our study and that the majority of those filed were rejected by the deputy district attorney. Although we did not examine the reason why so few postcertifications petitions are filed by clinicians, our anecdotal experience is that when clinicians encounter dangerous mentally ill patients, they perceive extended commitment under the danger-to-others criterion as "unwinnable." This perception could have been established prior to the study period. Instead of always filing for extended commitment, they often pursue commitments under more "winnable" criteria, such as grave disability (the inability to provide for one's basic needs). This strategy, while allowing for more hospital time for psychiatric and behavioral stabilization, is a less than ideal solution and is not always successful, because the "danger to others" patients are frequently able to meet the minimal legal criteria for the ability to care for oneself.

We believe that the application of the legal standard for the postcertification of dangerous psychiatric patients could be enhanced. What constitutes "a serious threat of substantial physical harm upon the person of another" appears to be too narrowly interpreted by legal professionals. Attorneys and judges could be better educated about the models identifying risk factors for violence that clinicians consider when assessing and identifying an individual's potential to harm others. If legal professionals understand how clinicians approach this concept and recognize that a verbal threat of harm is a legitimate criterion for extended hospitalization, they may not be as likely to reject it.

\section{Acknowledgment}

The authors wish to acknowledge Howard Kelner, JD, for his assistance.

\section{References}

1. Donaldson v. O'Connor, 493 F.2d 507 (5th Cir. 1974)

2. Wyatt v. Stickney, 344 F.Supp. 373 (M.D. Ala. 1972)

3. Lessard v. Schmidt, 349 F.Supp. 1078 (E.D. Wis. 1972)

4. Petersen v. State, 671 P.2d 230 (Wash. 1983)

5. Perriera v. State, 768 P.2d 1198 (Colo. 1989)

6. Naidu v. Laird, 539 A.2d 1064 (Del. 1988)

7. Alaska Stat. $\S 47.30 .740$ (Michie 1994)

8. Cal. Welf. \& Inst. Code $\S 5300$ (West 1994)

9. Wash. Rev. Code Ann. § 71.05.280 (West 1994)

10. Cal. Welf. \& Inst. Code $\$ 5150$ (West 1994)

11. Cal. Welf. \& Inst. Code $\S 5250$ (West 1994)

12. Cal. Welf. \& Inst. Code $\$ 5301$ (West 1994)

13. Cal. Welf. \& Inst. Code $\S 5114$ (West 1994)

14. Zeiss RA, Tanke ED, Fenn HH, Yesavage JA. Dangerousness commitments: indices of future violence potential? Bull Am Acad Psychiatry Law 24:247-53, 1996

15. Reynolds HT: The Analysis of Cross-Classifications: An Introduction for Social Scientists. New York: Free Press, 1977

16. Swanson JW: Mental disorder, substance abuse, and community violence: an epidemiological approach, in Violence and Mental Disorder. Edited by Monahan J, Steadman HJ. Chicago: University of Chicago Press, 1994

17. Zona MA, Sharma KK, Lane J: A comparative study of erotomanic and obsessional subjects in a forensic sample. J Forensic Sci 38: 894-903, 1993

18. Harmon RB, Rosner R, Owens H: Obses sional harassment and erotomania in a criminal court population. J Forensic Sci 40:188 96, 1995

19. Monahan J, Steadman HJ: Towards a rejuvenation of risk assessment research, in Violence and Mental Disorder. Edited by Monahan J, Steadman HJ. Chicago: University of Chicago Press, 1994

20. Gardner W, Lidz CW, Mulvey EP, Shaw EC: A comparison of actuarial methods for identifying repetitively violent patients with mental illnesses. Law Hum Behav 20:35-48, 1996

21. Tarasoff $v$. The Regents of the University of California et al., 55I P.2d 334 (Cal. 1976) 


\section{Extended Civil Commitment}

22. Felthous AR: The duty to protect, in Principles and Practice of Forensic Psychiatry. Edited by Rosner R. New York: Chapman \& Hall, 1994

23. Levenson JL: Psychiatric commitment and involuntary hospitalization: an ethical perspective. Psychiatr Q 58:106-12, 1986

24. Brown J, Rayne JT: Some ethical consider- ations in defensive psychiatry: a case study. Am J Orthopsychiatry 59:534-41, 1989

25. Hiday VA, Smith LN: Effects of the dangerousness standard in civil commitment. J Psychiatry Law 15:433-54, 1987

26. Hiday VA: Dangerousness of civil commitment candidates: a six month follow-up. Law Hum Behav 14:551-67, 1990 